\title{
Case study: Dust in the housing of laying birds
}

\author{
Estudo de caso: Em alojamento de aves poedeiras \\ Caso de estudio: Polvo en el alojamiento de aves ponedoras
}

Received: 02/20/2021 | Reviewed: 02/28/2021 | Accept: 06/11/2021 | Published: 06/24/2021

Adriana Maria dos Santos

ORCID: https://orcid.org/0000-0002-5070-6111 Universidade Federal de Campina Grande, Brazil

E-mail: ttstadriana@gmail.com

Dermeval Araújo Furtado

ORCID: https://orcid.org/0000-0003-4511-571X Universidade Federal de Campina Grande, Brazil

E-mail: araujodermeval@gmail.com

José Pinheiro Lopes Neto

ORCID: https://orcid.org/0000-0003-4960-5679 Universidade Federal de Campina Grande, Brazil E-mail: lopesneto@gmail.com

Fabiana Terezinha Leal de Morais ORCID: https://orcid.org/0000-0003-4924-990X Universidade Federal de Campina Grande, Brazil E-mail: fabianaleal_morais@hotmail.com Rafael Costa Silva

ORCID: https://orcid.org/0000-0001-5742-3707 Universidade Federal de Campina Grande, Brazil E-mail: rafael_brazil@hotmail.com

Daniele Ferreira de Melo

ORCID: https://orcid.org/0000-0002-6740-1971 Universidade Federal de Campina Grande, Brazil E-mail: danimelo.ufcg@hotmail.com

\begin{abstract}
As dust particles in laying poultry houses can have negative effects on health and on the environment,this study aimed to measure and compare dust concentrations in egg production sheds. The experiment was carried out in three sheds: Californian shed (G1), conventional closed shed with artificial ventilation (G2) and conventional closed shed without artificial ventilation (G3), and the birds housed were in the 22nd week of housing, in Cuité, Paraíba, Brazil.The dust particles were collected by a gravimetric pump, attached to the workers' clothes, at the height of the respiratory zone, being removed at the end of the working day. Using the evaluation methodologies (total or breathable dust) according to NIOSH (1998), weighing was performed with sample concentration calculation, then the particle size was measured by microscopy according to the methodology described by Feret(Santos, 2001), with diameter of function obtained using an optical microscope, and particles classified by size (inhalable $<100 \mu \mathrm{m}$, thoracic $<25 \mu \mathrm{m}$ and breathable $<10 \mu \mathrm{m}$ ). Considering the limit of concentration x exposure time of $3.0 \mathrm{mg} / \mathrm{m} 3$, according to ACGIH (2013), the sheds had the following values: G1-0.98 mg/m3, G2-1.45 mg/m3 and G3-1.13 mg/m3. In the classification of particles by size, the highest frequencieswere $83 \%$ thoracic, $13 \%$ inhalable, and $4 \%$ breathable. With the results presented, the implementation of the Respiratory Protection Program - PPR is suggested.
\end{abstract}

Keywords: Animal production; Chemical risk; Bioaerosols.

\section{Resumo}

As emissões de poeira de aves de postura em grande escala podem ter impactos negativos à saúde e ao meio ambiente. Desta forma, o presente estudo objetivou medir e comparar as concentrações de poeira em ambientes de trabalho de galpões de poedeira. As medições de poeira foram realizadas durante um ciclo produtivo/dia em três galpões: galpão convencional (com e sem ventilação artificial) e galpão californiano, localizados no nordeste brasileiro. Para as variáveis ambientais (temperatura, umidade, velocidade do ar, carga térmica radiante e índice de bulbo úmido) foi utilizado equipamento analisador de ambiente multi-funções conectado a microcontrolador Arduino. A poeira foi coletada por bomba gravimétrica, calibrada para uma vazão de $1,7 \mathrm{~min}$. L-1 de ar com 5\% de variação admitida, acopladas a ciclone de poeira respirável com cassete, contendo filtro de membrana de PVC (polímero de cloreto de polivinila) de $5 \mu \mathrm{m}$ de poro e $37 \mathrm{~mm}$ de diâmetro previamente esterilizado. As bombas de amostragem foram acopladas a vestimenta do trabalhador, sendo retiradas ao final do dia de trabalho, o tamanho da poeira coletada foi analisado medição do tamanho das partículas por microscopia foi o diâmetro de Feret com o uso de microscópio ótico, com aumento óptico em 5x. Dentre as variáveis do ambiente, umidade e ventilação do ar estiveram dentro do que 
prescreve a NR-17, ergonomia, já temperatura este acima do desejado de $20^{\circ} \mathrm{C}$ e $23^{\circ} \mathrm{C}$, no entanto para as aves, os galpões G1 e G2 mostraram condições térmicas adequadas, dentro dos limites de 21 e $28^{\circ} \mathrm{C}$. A poeira analisada, em sua quantidade mostrou-se acima dos limites recomendados para poeira animal de $0,23 \mathrm{mg} / \mathrm{m} 3$ para poeira animal, nos tamanhos e dimensões a maior frequência $(42 \%)$ à poeira torácica $(<25 \mu \mathrm{m})$ e inalável $(<100 \mu \mathrm{m})$.

Palavras-chave: Produção animal; Risco químico; Bioaresois.

\section{Resumen}

Las emisiones de polvo de las aves ponedoras a gran escala pueden tener impactos negativos en la salud y el medio ambiente. Por lo tanto, el presente estudio tuvo como objetivo medir y comparar las concentraciones de polvo en entornos de trabajo de los cobertizos de polvo. Las mediciones de polvo se realizaron durante un ciclo de producción/día en tres cobertizos: cobertizo convencional (con y sin ventilación artificial) y galpón californiano, ubicado en el nordeste de Brasil. Para las variables ambientales (temperatura, humedad, velociade de aire, carga térmica radiante e índice de bulbo húmedo) se utilizó un equipo analizador de entorno multifunción conectado al microcontrolador Arduino. El polvo fue recogido por la bomba gravimétrica, calibrada para un caudal de 1,7 min. Aire L-1 con 5\% de variación permitida, acoplado a un ciclón de polvo transpirable con casete, que contiene filtro de membrana de PVC (polímero de cloruro de polivinilo) de poro de $5 \mu \mathrm{m}$ y $37 \mathrm{~mm}$ de diámetro previamente esterilizado. Las bombas de muestreo se acoplaron a la ropa del trabajador, siendo retiradas al final de la jornada laboral, los tamaños del polvo recogido, la medición del tamaño de partícula por microscopía fue el diámetro de Feret con el uso de microscopio óptico, con aumento óptico en 5x. Entre las variables del ambiente, la humedad y la ventilación del aire se encontraban dentro de lo que prescribe la NR-17, ergonomía, ya temperatura por encima de la deseada de $20^{\circ} \mathrm{C}$ y $23^{\circ} \mathrm{C}$, sin embargo para las aves, los galpones G1 y G2 mostraron condiciones térmicas adecuadas, dentro de los límites de 21 y $28^{\circ} \mathrm{C}$. El polvo analizado en su cantidad estuvo por encima de los límites recomendados para polvo animal de $0,23 \mathrm{mg} / \mathrm{m} 3$ para polvo animal, en los tamaños y dimensiones la frecuencia más alta $(42 \%)$ pecho $(<25 \mu \mathrm{m})$ e inalerable $(<100 \mu \mathrm{m})$.

Palavras chave: Producción animal; Riesgo químico; Bioaresois.

\section{Introduction}

In meatand laying poultry production systems, air quality can be affected by high dust concentrations (Le Bouquin, 2019), which can cause health problems in employees and animals (Cambra-Lopez, 2011). Diseases induced by inhalation of different bioaerosols are related not only to their biological properties and chemical composition, but also to the number of inhaled particles and the place where they deposit in the respiratory system.

Bird sheds are environments that can generate excessive dust, which originates from the bed, fiberglass insulation materials, food, dry fecal materials and feather particle (Cambra-Lopez et al., 2011). Dust can contain microorganisms, including endotoxins, fungi and bacteria, which can affect living beings when inhaled, (Wang \& Ogawa 2015) with dust containing living organisms referred to as bioaerosol and its particle can range from 0.5 to $100 \mu$ m. Regulatory Standard 9 , item 9.1.5.3 mentions that bacteria, fungi, bacilli, parasites, protozoa, viruses, among others, are considered biological agents, and the risk of contamination may be increased, since workers may not be wearing gloves and masks (Santos et al., 2014).

Exposure to organic powder is a health problem for workers in breeding environments and this exposure can occur through inhalation, contact with the skin or through the gastrointestinal system. However, for respiratory health in agriculture, where organic dust may be contaminated, inhalation is an important route of exposure (Dalólio et al., 2016).

NIOSH (1998) determines the classification of dimensions by size (inhalable $<100$ um, thoracic $<25$ um and breathable $<10 \mathrm{um}$ ) and as assessment methods (total or breathable dust).

In this context, the study aims to measure and compare dust concentrations in egg production sheds.

\section{Methodology}

The study was carried out in poultry production units (eggs), and the sheds are located in Cuité - Paraíba, Brazil, At $06^{\circ} 29^{\prime} 01$ "S latitude and $36^{\circ} 09^{\prime} 13^{\prime \prime} \mathrm{W}$ longitude. The experiment was carried out in the production phase, in different types of sheds: Californian shed (G1), conventional closed shed with artificial ventilation $(\mathrm{G} 2)$ and conventional closed shed without 
artificial ventilation (G3), and the birds housed were in the 22nd week of housing, types of sheds classified according to (Brito et al.,2020)

The collection of breathable dust was carried out during 1 day of production and repeated in the three sheds, totaling one sample for each shed. The methodology used was defined by NIOSH (OSHA, 1994), using the BDX-II sampling pump (brand: Sensidyne), calibrated for air flow rate of $1.7 \mathrm{~L} \mathrm{~min}-1$ with acceptable variation of 5\%, coupled to the breathable dust cyclone with cassette, containing a $5 \mu \mathrm{m}$ PVC (polyvinyl chloride polymer) membrane filter with a diameter of $37 \mathrm{~mm}$, previously sterilized. The devicewas attached to the worker's clothing at the heightof the respiratory zone and removed at the end of the workday.

Study of collected material:

1- Weighing membrane filters before and after collection.

2- Image recording on the glass slide, with Olympus BX51 optical microscope - 5x optical magnification.

3- Size study, with Olympus Imaging Solution software, where the equivalent diameter is given by the length of any linear intersection, evaluating the distance between two lines tangent to the particle's projection, in a pre-fixed direction (horizontal and vertical). The method used to measure the particle size by microscopy was the diameter of the functions, which determines the distance between two tangent lines and the design of verification in the horizontal and vertical bars, providing information about size, shape and color, called the FERET method (Santos, 2001).

4- To express the results, the calculation of the sample concentration was performed based on ACGIH - American Conference of Governmental Industrial Hygienists (1998), according to the instructions and expression of NHO-08 for the collection of solid particulate material suspended in the work environment (Fundacentro, 2009).

\section{Results and Discussion}

In the collection carried out in the 3 sheds, the largest amount of dust was found in G2, so it is possible to infer that the use of artificial ventilation and the increase in air speed help to remove dust from the environment, whereas G1 had the lowest amount. This shed has side openings that increase the air flow and take the dust to the external environment; another difference is the number of hens housed, height of the cages $(1.30 \mathrm{~m})$, whereas in $\mathrm{G} 2$ and $\mathrm{G} 3$, the height of the cages reaches more than $3.0 \mathrm{~m}$, for the worker who walks in the shed, and the amount of dust released in the galleries over the respiratory zone.

Table 1. Dust collected by shed.

\begin{tabular}{crc}
\hline Collection location & \multicolumn{2}{c}{ Sample concentration } \\
& \multicolumn{2}{c}{ Weight/day } \\
\hline G1 & $0.80 \mathrm{mg}$ & $0.98 \mathrm{mg} / \mathrm{m}^{3}$ \\
G2 & $1.19 \mathrm{mg}$ & $1.45 \mathrm{mg} / \mathrm{m}^{3}$ \\
G3 & $0.93 \mathrm{mg}$ & $1.13 \mathrm{mg} / \mathrm{m}^{3}$ \\
\hline
\end{tabular}

Considering the LEO - Occupational Exposure Limit,the maximum concentration is related to the nature and time of exposure to the product, which will not cause damage to the health of the worker during his working life undercondition of 8 hours of daily exposure. It is noted in the results of the evaluations that the tolerance limits stipulated by ACGIH (2013) in both jobs were not exceeded.

According to the classification of particles by size (inhalable $<100 \mu \mathrm{m}$, thoracic $<25 \mu \mathrm{m}$ and breathable $<10$ $\mu \mathrm{m}$ ) of NIOSH (1998), (figure 1) the results found in the present study were 13\% inhalable, $83 \%$ thoracic and $4 \%$ 
breathable.These particles can easily penetrate the respiratory system and transport microorganisms and fragments related to activities in the environment, such as food scraps, feathers and animal skins.

Figure 1. Particle size for the samples collected (inhalable, thoracic and breathable).

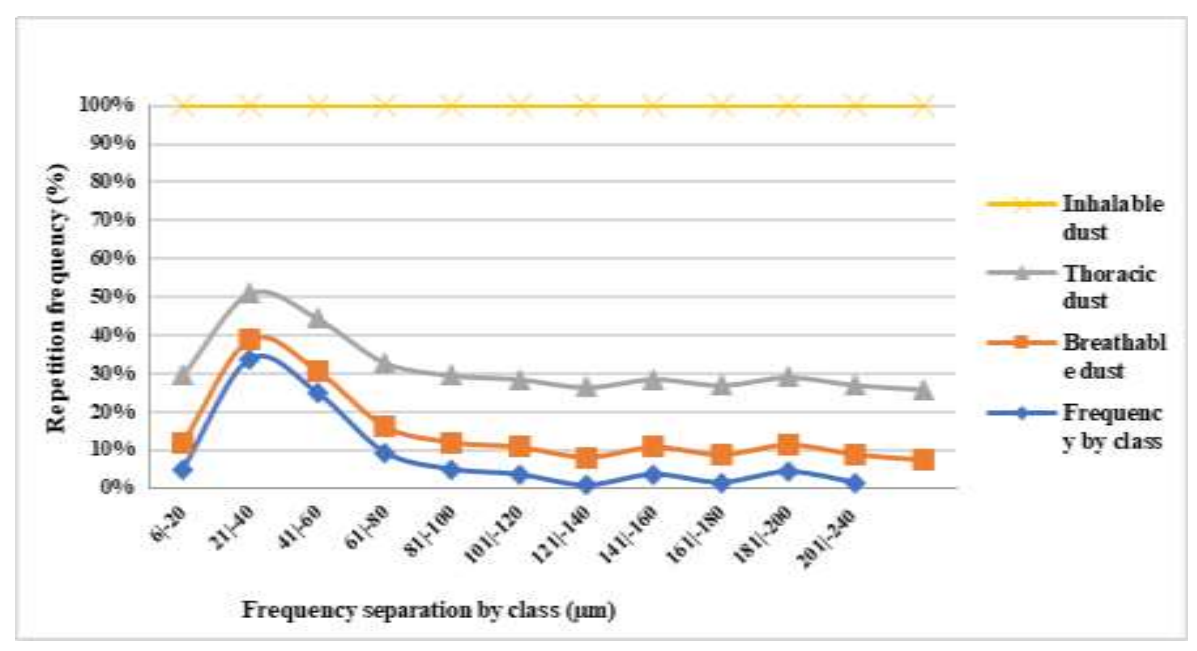

Source: Authors (2020).

Even with fractions above $100 \mu \mathrm{m}$, in $17 \%$, the existence of smaller dust particles cannot be ruled out (Figure 1).In terms of occupational health, ultra-fine particles may be more toxic than larger particles due to their aspects of deposition and disposition in the worker's body, but particles with the largest surface area by mass can act as a catalyst for reactions and theirincreased surface area could act as a transporter for microorganisms.

(Takai et al., 1999), in closed and controlled environment sheds, for laying hens, found that the concentration of inhaled dust, fraction $<100 \mu \mathrm{m}$ of total dust, varied from $3.83 \mu \mathrm{m}$ to $10.4 \mu \mathrm{m}$ and with the means of dust inactivation around $3.60 \mu \mathrm{m}$.

According to Regulatory Norm NR-09 (2015),the following practices should be adopted: periodic monitoring, information to workers and medical control of all those exposed to the total dust risk of this activity, besides the implementation of the Respiratory Protection Program - PPR, which can be selected as ventilation control measure, indispensable to maintain dust levels, use of EPI (PFF2 mask) - facial filter, with efficiency of at least $94 \%$, and protection of air ways against dust and biological agents, both in collecting eggs and cleaning the sheds.

\section{Conclusion}

Considering LEO / 8 hours daily, the amount does not exceed the tolerance limits, since in the classification of particles by size, thoracic dust was the most present, with $83 \%$. To promote healthiness in these work environments, a Respiratory Protection Program that includes monitoring and safety measures should be adopted.

This study stresses the need for information and studies on air filtration in sheds, efficacy in the use of facial protectors and constructive adaptations of sheds for better air quality, among others, questions about this line of occupational hygiene and animal welfare begin here. 
Research, Society and Development, v. 10, n. 7, e35510713170, 2021

(CC BY 4.0) | ISSN 2525-3409 | DOI: http://dx.doi.org/10.33448/rsd-v10i7.13170

\section{References}

ACGIG (2013). American Conference of Governmental Industrial Hygienist. Limites de exposição (TLVs) para substâncias químicas e agentes físicos e índices biológicos de exposição (BEIs). Associação Brasileira de Higienistas Ocupacionais.

Brito, A. N. dos S. L. de; Lopes Neto, J. P.; Furtado, D. A.; Mascarenhas, N. M. H.; Oliveira, A. G. de; Gregório, M. G.; Dornelas, K. C.; Laurentino, L. G. de S. \& Rodrigues, H. C. S. (2020) Thermal performance of poultry sheds for broiler chicken: review of different types of coverings . Research, Society and Development, 9, e474997608, 2020. 10.33448/rsd-v9i9.7608.

Cambra-Lopez, M. T.; Hermosilla, H. T. L.; Lai, A. J. A. \& Aarnink N. W. (2011). M;Source identification and quantification of particulate matter emitted from livestock houses. Trans. ASABE 54:629-642.

Dalólio, F. S.; Moreira, J.; Vaz, D. P.; Albino, L. F. T.; Valadares, L. R.; Pires, A. V. \& Pinheiro, S. R. F. (2016). Exogenous enzymes in diets for broilers. Revista Brasileira de Saúde e Produção Animal, 17(2), 149-161.

Le Bouquin S.; Huneau-Salaun A.; Huonnic D.; Balaine L.; Martin S. \& Michel V. (2019). Aerial dust concentration in cage-housed, floor-housed, and aviary facilities for laying hens. Poultry Science Association. 1. 2827 -2833.

NHO 08. (2009). FUNDACENTRO. Coleta de Material Particulado. Sólido Suspenso no Ar de Ambientes de Trabalho. Procedimento Técnico. Fundacentro. MINISTÉRIO DA ECONOMIA.2020. NR 9: Programa de Prevenção de Riscos Ambientais. Brasil. (2015). 7 p. https://enit.trabalho.gov.br/portal/images/ Arquivos_SST/SST_NR/NR-09-atualizada-2019.pdf>.

National Institute for Occupational Safety and Health - NIOSH.(1994). Particulates not otherwise regulated, total. Method 0500. In: Schelech, P.C.; O'Connor, P.F. (Eds.). NIOSH Manual of analytical methods (NMAM®). (4th ed.), http://www.cdc.gov/niosh/docs/2003-154/pdfs/0500.pdf.

National Institute for Occupational Safety and Health - NIOSH.(1998). Particulates not otherwise regulated, respirable. Method 0600.In: Schelech, P.C.; O'Connor, P.F. (Eds.). NIOSH Manual of analytical methods (NMAM®). (4th ed.), http://www.cdc.gov/niosh/docs/2003-154/pdfs/0600.pdf.

Santos, A. M. A.(2001). O tamanho das partículas de poeira suspensas no ar dos ambientes de trabalho. Fundacentro.

Takai, H.; Seedorf, J. \& Pedersen, S.;(1999). Dust and endotoxin concentrations in livestock buildings in norther Europe. In: International Symposium On Dust Control In Animal Production Facilities, 1. Aarhus: Danish Institute of Agricultural Sciences, p.140-53.

Wang, J. \& Ogawa, S. (2015) Effects of meteorological conditions on PM2.5 concentrations in Nagasaki, Japan. International Journal of Environmental Research and Public Health, 12, 9089-9101. 